\title{
Influence of financial sustainability of households on default risks of regulated banks
}

\author{
Zuhra Yergasheva ${ }^{1}$, Saltanat Kondybayeva ${ }^{1, *}$, Ryszhan Kabylkairatkyzy ${ }^{1}$ and Gulmira \\ Yesengeldiyeva $1^{1}$ \\ ${ }^{1}$ Al-Farabi Kazakh National University, al-Farabi Ave. 71, 050040 Almaty, Kazakhstan
}

\begin{abstract}
The purpose of the article is to assess the financial sustainability of the household sector of the Republic of Kazakhstan and its impact on the real and financial sector in the context of minimizing the credit risks of the regulated banks of the Republic of Kazakhstan. The paper analyzes various points of view on assessing the financial sustainability of the household sector, makes a successful attempt to assess at a macroeconomic level the financial sustainability of households and the drawing potential of households in Kazakhstan using the OECD and IMF methods. The work made a holistic analysis of the financial condition and solvency of households in Kazakhstan, a forecasted VAR-model for assessing the impact of household financial sustainability on the state of the real sector of the economy has been developed; a regression model for assessing the impact of financial stability of households on the financial sector of Kazakhstan has been developed.
\end{abstract}

\section{Introduction}

In the conditions of development of market relations, the problems and prospects of consumer lending to individuals are becoming particularly relevant in the financial market. Banking services to individuals in foreign practice is a widespread financial service provided by banks. Problems of non-repayment of loans by individuals lead to a deterioration in the quality of bank credit portfolios, an increase in the NPL level, which in turn increases the amount of necessary provisions. In these conditions, banks are forced to make increased demands on the financial sustainability of retail borrowers. In Kazakhstan, improving the financial sustainability of households is the task of the utmost importance, since the level and quality of life of the vast majority of the population is significantly inferior not only to highly developed countries, but also to many developing countries.

Financial sustainability is a new scientific topic in economics. Its importance has increased significantly during the global economic crises that began in 2008. The global financial crisis has identified risks that the household sector may pose to financial sustainability and the financial system.

The financial sustainability of households is determined by determining the financial vulnerability of households. Empirical studies of household financial vulnerability over the

\footnotetext{
${ }^{*}$ Corresponding author: saltanatkondybayeva@gmail.com
} 
past decade have spread and fostered the sharing of knowledge and best practices. Nevertheless, a consistent knowledge structure in this area is still lacking; problems and gaps still remain.

\section{Literature review}

A number of scientific papers are devoted to issues related to assessing financial sustainability, in which the problem of financial sustainability is discussed in various aspects: in terms of financial analysis, from the point of view of assessing household balances, from the point of view of assessing the influence of a regional factor on the financial condition of economic entities and their sustainability, from the point of view of determining ways to improve the assessment of financial sustainability.

After the financial crisis, the issues of financial sustainability were given close attention by both national authorities of different countries and international organizations. For example, Albacete and Fessler devoted work to determine the financial vulnerability of households based on data from Austrian households, and then conducted stress testing to determine the impact of macroeconomic shocks on the financial sustainability of households [1]. The authors of Tom Bilston and David Rodgers in their research define two types of definition of financial sustainability: "financial spread" and "threshold" approaches [2]. It should be noted that this model used in this work is in many ways similar to the model in Albacete and Fessler. These authors also investigated the effect of household financial sustainabilityon the credit risks of banks, for which they first calculated the PD, LGD indicators and, using these indicators, determined the debt-at-risk.

The work of another author K. Galuschak is very similar to the previous one, there is one difference, it considers the probability of the transition of an unemployed person to an employed person, while the work of Tom Bilston and David Rodgers shows a situation where a person moved from the employed to the unemployed category [3].

Although these studies and documents were aimed at business borrowers, Handm, D (2001) [4], Allen, L., DeLong, G., Saunders, A. (2004) [5], Bartolozzi E., Garcia-Erguin L., Deocon C., Vasquez O., Plaza F. (2008) [6] consider issues and methods for modeling retail loans. Martin V., Evien K. [7] describe several modeling methods, including linear discriminant analysis (LDA) and logistic regression (LR), and try to answer the question: "Which is the best method?" Studies by Pohar M., Blas M., Turk S. [8] show that LDA and LR give similar results only in cases where the assumptions about normality are not violated. Webster G. (2011) [9] explores logistic regression when there is evidence of the number and presence of problems. Berry M., Linoff. G. [10] introduced practical questions of data mining, Siddiqi N. [11] studied the process of building credit scoring.

\section{Methods and materials}

According to Nesterov's [12] methodology, which applies the model of the organization's marketing environment proposed by Kotler to the concept of financial sustainability of household, parameters such as the internal environment, the near and far surroundings of the household, which affect the financial sustainability of households, were identified.

External factors affecting the financial sustainability of a household are such macroeconomic variables as socio-economic crises, the cyclical nature of economic development, inflation, and features of the labor market.

The factors presented in table number 1 and in figure 1, determine two types of conditions in which households conduct their financial activities: conducive conditions (various types of sources of income are created, all family members are employed, etc.) and 
adverse conditions (temporary disability, lack of employment, etc.).

Table 1. Classification of factors of financial sustainability of the household proposed by Nesterov [12].

\begin{tabular}{|l|l|l|l|l|}
\hline \multicolumn{5}{|c|}{ Factors } \\
\hline $\begin{array}{l}\text { Impact } \\
\text { factors }\end{array}$ & Leverage & $\begin{array}{l}\text { Form of } \\
\text { impact }\end{array}$ & $\begin{array}{l}\text { Nature of the } \\
\text { impact }\end{array}$ & Inter subordination \\
\hline external & weak & hidden & direct & basic \\
\hline inner & reasonable & exact & indirect & intermediate \\
\hline & strong & & & \\
\hline
\end{tabular}

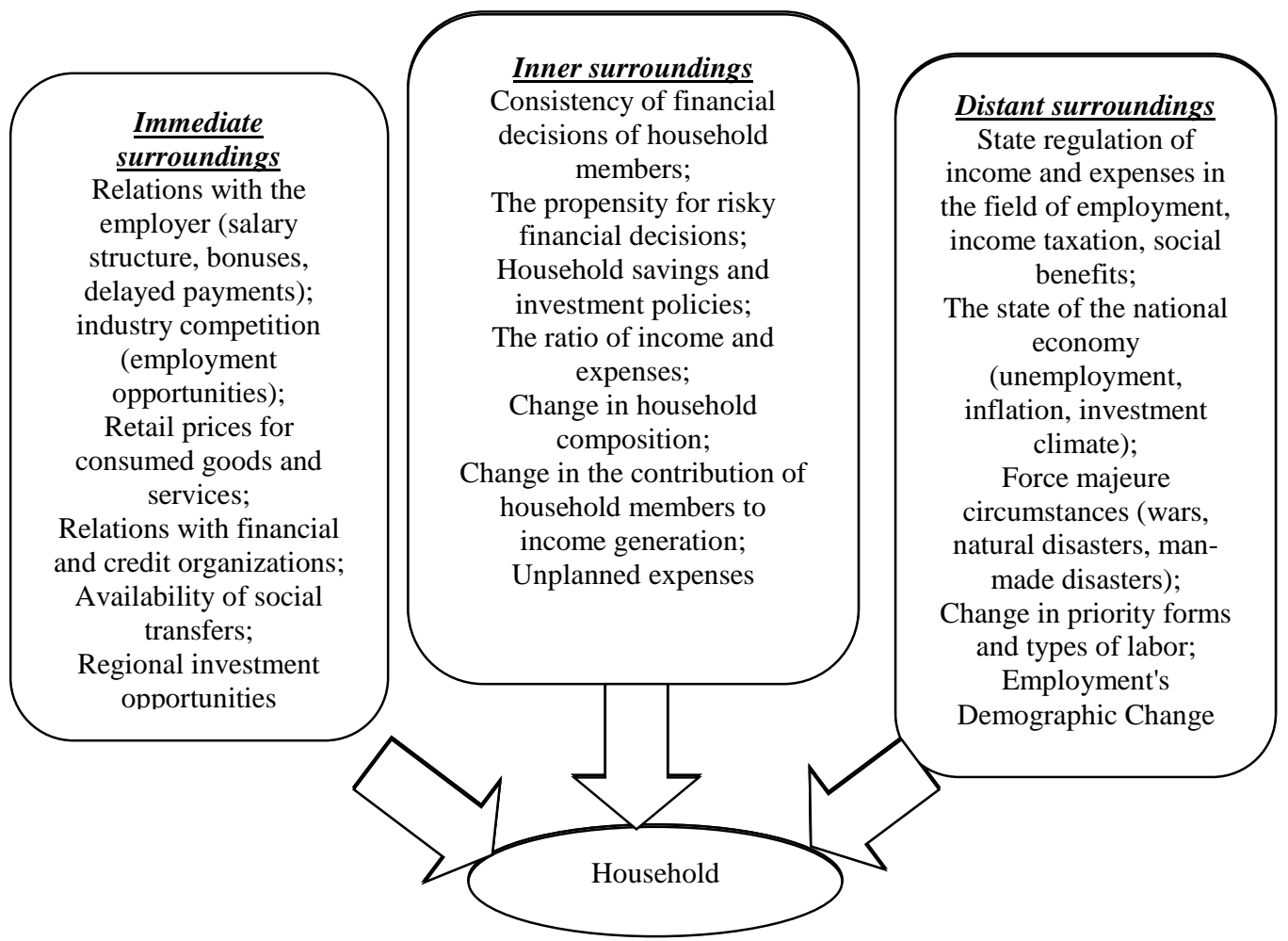

Fig. 1. Factors affecting the financial sustainability of a household [12].

Debt household research suggests two competing paradigms: the first relates to the solvency of individual households, and the second to the liquidity of the financial situation. Based on the definition of solvability, many household study authors associate financial vulnerability of households with gross or net debt, as measured by the ratio of debt to assets (Albacete and Linder) [13] or the ratio of debt to income. Instead, liquidity-based household financial vulnerability indicators are linked to current debt repayments or to budget constraints such as DSTI ratios and so-called "financial spreads", the latter being defined as the difference between household income and estimated minimum expenses and debt payments.

Studies that used the "threshold" approach (the DSTI indicator was mainly used): Dey et al. (2008) [14], Karasulu (2008) [15], Djoudad (2011) [16], IMF (2012) [17], ECB (2014) [18], Michelangeli and Pietrunti (2014) [19], Ruiz Arranz (2014) [20]. Studies that used the "financial spreads" approach: Albacete and Fessler (2010) [1], Hlavac et al. (2014) 
[21], Bilston et al. (2015) [22], Meriküll and Room (2017) [23].

A sampling inquiry of Kazakhstan households has been conducted since 2001 on a quarterly basis. The survey involved 12 thousand households. Using A sampling inquiry of households, they obtain statistical information on the level and structure of cash incomes and expenses, on the degree of economic activity of the population, assessment of living standards, household consumption and other important information. This inquiry is aimed at obtaining quantitative data and complies with international standards. With help from these data, it is possible to assess the solvency of households, the distribution of their income in the regional context, by type of population, what kind of disposable income they have.

There is no consensus in the literature regarding the definition of over-indebtedness and, therefore, on how to measure it. Some studies of over-indebtedness (BIS, 2019 [24], Keese, 2009 [25]) converge on a common set of indicators, while noting that there is no universal indicator that would best reflect true excessive debt. The indicators generally reflect four aspects of debt: high payments in relation to income, there are overdue debts, intensive use of credit and debt burden (Table 2).

Table 2. Household over-indebtedness Indicators.

\begin{tabular}{|l|l|}
\hline Category & Indicator \\
\hline Debt-service costs & $\begin{array}{l}\text { Households that spend more than 30\% (or 50\%) of their monthly } \\
\text { gross income on repayment of a loan (secured and unsecured) }\end{array}$ \\
\cline { 2 - 2 } & $\begin{array}{l}\text { Households spend more than 25\% of their gross monthly income on } \\
\text { unsecured payments }\end{array}$ \\
\cline { 2 - 2 } & $\begin{array}{l}\text { Households whose expenses on repaying common borrowings make } \\
\text { them fall below the poverty line }\end{array}$ \\
\hline Arrears & $\begin{array}{l}\text { Households that have overdue arrears on a credit or house accounts } \\
\text { for more than 2 months }\end{array}$ \\
\hline Amount of credits & Households with 4 or more credit obligations \\
\hline $\begin{array}{l}\text { Subjective } \\
\text { perception }\end{array}$ & $\begin{array}{l}\text { Households announcing that their borrowing payments are a "heavy } \\
\text { burden" }\end{array}$ \\
\hline Note - compiled by the author based on the source [26] \\
\hline
\end{tabular}

\section{Macroeconomic Model for Assessing the Impact of Sustainability of the Household Sector on Credit Risks}

The authors developed an empirical model for the indicator of non-performing household loans, since this indicator is an important part of the information for analyzing the financial vulnerability of households. The data included in the model is quarterly, from the 1 st quarter of 2008 to the 2nd quarter of 2018 [27].

$$
n p l_{i, t}=f\left(\text { debt }_{t}, \text { disp_income }_{t}, \text { assets }_{t}, \text { infl }_{t}, \text { real len }, \text {, housing_price }, \text {, unempl } t_{t}\right)
$$

where, $n p l_{t}$ - the logarithm of the ratio of non-performing household loans to total household loans at time $\mathrm{t}$ is a proxy indicator of the financial vulnerability of this sector;

$d e b t_{t}$ - the logarithm of the ratio of total debt (including mortgages, consumer loans and other loans) to household disposable income;

income $_{t}-$ logarithm of disposable income per household;

assets $_{t}$-the logarithm of the ratio of gross financial assets of households to disposable income;

real len - rate per cent;

unempl $_{t}$ - number of unemployed people; 
infl $l_{t}$ - inflation.

These are the main variables of the model, the probability determinants of being in a difficult position when repaying a loan. The authors also added several other variables that appear to be relevant to the empirical literature investigating household borrowing. These are housing prices (housing_price t $_{\text {) }}$ to account for the variability of housing wealth; real GDP growth (real_gdp_gr), real effective exchange rate $\left(\right.$ reer $\left._{t}\right)$.

Table 3. Regression equation 1, with the dependent variable NPL in the statistical package Eviews.

\begin{tabular}{|l|r|r|r|r|}
\hline \multicolumn{1}{|c|}{ Variable } & \multicolumn{1}{|c|}{ Coefficient } & \multicolumn{1}{c|}{ Std. Error } & \multicolumn{1}{c|}{ t-Statistic } & \multicolumn{1}{c|}{ Prob. } \\
\hline D(DEBT(-4)) & 0.034301 & 0.005394 & 6.358799 & 0.0014 \\
\hline D(INCOME(-5)) & -0.005955 & 0.000917 & -6.496267 & 0.0013 \\
\hline LOG(D(ASSETS(-3))) & -0.069308 & 0.005880 & -11.78729 & 0.0001 \\
\hline D(UE_PEOPLE) & 0.024487 & 0.002710 & 9.035139 & 0.0003 \\
\hline D(REAL_GDP_GR(-2)) & -0.041924 & 0.007558 & -5.547252 & 0.0026 \\
\hline D(REER(-1)) & 0.004762 & 0.001173 & 4.059372 & 0.0097 \\
\hline C & 2.394039 & 0.013303 & 179.9556 & 0.0000 \\
\hline \hline R-squared & 0.975536 & Mean dependent var & 2.313723 \\
\hline Adjusted R-squared & 0.946178 & S.D. dependent var & 0.089568 \\
\hline S.E. of regression & 0.020779 & Akaike info criterion & -4.618512 \\
\hline Sum squared resid & 0.002159 & Schwarz criterion & -4.335650 \\
\hline Log likelihood & 34.71107 & Hannan-Quinn criter. & -4.723238 \\
\hline F-statistic & 33.22987 & Durbin-Watson stat & 2.181921 \\
\hline Prob(F-statistic) & 0.000712 & & \\
\hline Note - compiled by the author on the statistical package Eviews. \\
\hline
\end{tabular}

The author constructed equation 1 . This equation includes such independent variables as household debt, disposable income per household, financial assets, unemployed population, real GDP growth rate, and real effective exchange rate. All factors are significant at level of importance $1 \%$. The signs of the variables are in line with expectations. Independent factors selected account for a 97\% change in the dependent variable NPL. As matter stands, the Durbin-Watson criterion is 2.18 , which is below the critical point, therefore, the H0 hypothesis about the absence of autocorrelation of residues is not accepted. Further, after some modifications, equation 2 was obtained.

Table 4. Regression equation 2, with the dependent variable NPL in the statistical package Eviews.

\begin{tabular}{|l|r|r|r|r|}
\hline \multicolumn{1}{|c|}{ Variable } & \multicolumn{1}{c|}{ Coefficient } & \multicolumn{1}{c|}{ Std. Error } & \multicolumn{1}{c|}{ t-Statistic } & \multicolumn{1}{c|}{ Prob. } \\
\hline D(DEBT(-1)) & 0.162613 & 0.053385 & 3.046058 & 0.0057 \\
\hline $\begin{array}{l}\text { D(D(CONSUMER_EXP(- } \\
\text { 3) })\end{array}$ & $2.58 \mathrm{E}-06$ & $9.86 \mathrm{E}-07$ & 2.612061 & 0.0156 \\
\hline $\mathrm{C}$ & 8.057271 & 5.105974 & 1.578008 & 0.1282 \\
\hline $\mathrm{AR}(1)$ & 0.931643 & 0.129477 & 7.195433 & 0.0000 \\
\hline $\mathrm{MA}(1)$ & 0.946131 & 0.025017 & 37.81888 & 0.0000 \\
\hline & & & & 10.38276 \\
\hline R-squared & 0.888812 & Mean dependent var & 1.048974 \\
\hline Adjusted R-squared & 0.869475 & S.D. dependent var & 1.057740 \\
\hline S.E. of regression & 0.378975 & Akaike info criterion & 1.295634 \\
\hline Sum squared resid & 3.303310 & \multicolumn{2}{|l|}{ Schwarz criterion } &
\end{tabular}




\begin{tabular}{|l|r|l|l|l|}
\hline Log likelihood & -9.808364 & Hannan-Quinn criter. & 1.130467 \\
\hline F-statistic & 45.96440 & Durbin-Watson stat & 1.969244 \\
\hline Prob(F-statistic) & 0.000000 & & & \\
\hline & & & & \\
\hline Inverted AR Roots & .93 & & \\
\hline Inverted MA Roots & -.95 & & \\
\hline \multicolumn{2}{|l|}{ Note - compiled by the author on the statistical package Eviews. } \\
\hline
\end{tabular}

In this equation, all variables are significant at an importance level of 5\%. Incoming independent variables account for a $88 \%$ change in the dependent variable. The Akaike and Schwartz criteria are less than in the previous equation, therefore, this equation is relatively better. NPLs are affected by an increase in household debt with a lag of 1 quarter and an increase in consumer spending with a lag of 3 quarters. Also, NPL depends on itself with a lag of 1 quarter, this is due to the inertia of this indicator. All variables have an adequate economic meaning. Of the several equations constructed, the author selected equation 2, since FinMark Trust and the Marketing Research Bureau identified a number of variables that are strong predictors of household financial vulnerability. They are: over-indebtedness, consumption (current expenses), financial vulnerability associated with income [28]. Just those variables that are included in equation 2 are predictors of financial vulnerability of households. And if the household is financially vulnerable, then there is a high probability of an increase in the NPL. Therefore, it is advisable to use this particular equation.
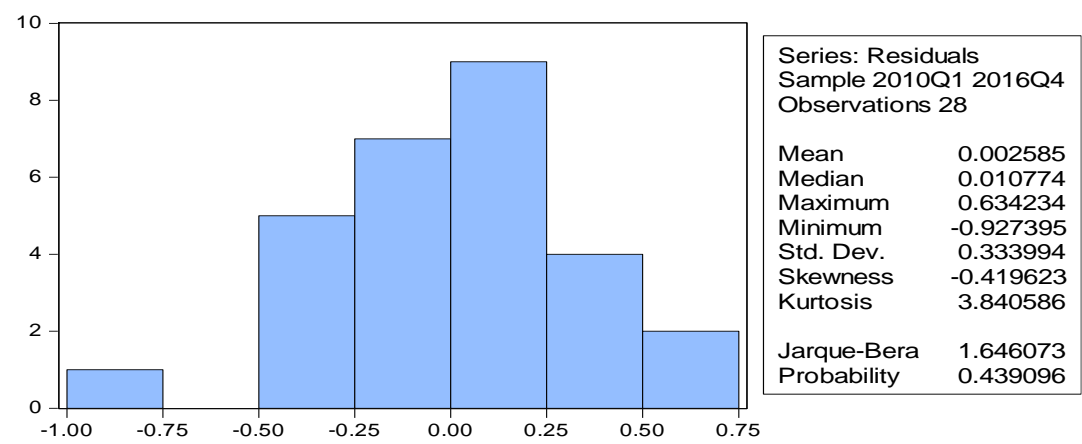

Fig. 2. Histogram-Normality test.

Note - compiled by the authors on the statistical package Eviews.

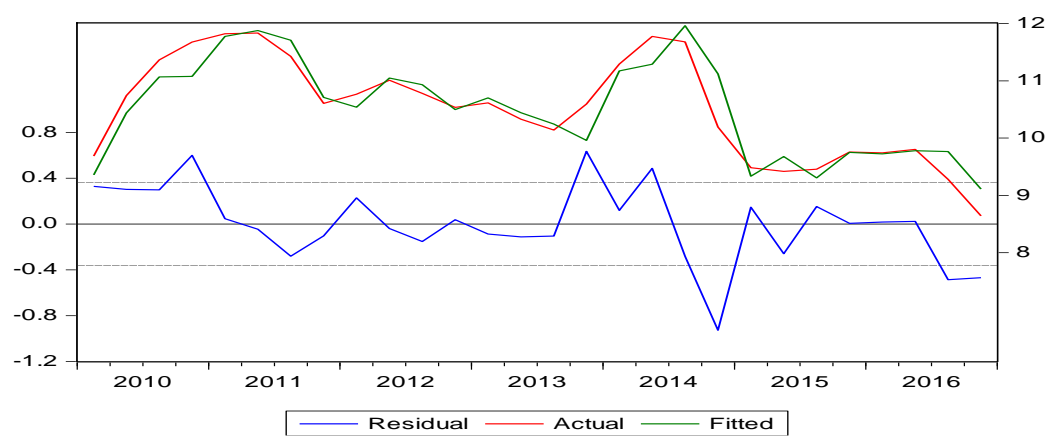

Fig. 3. Graph of residuals.

Note - compiled by the authors on the statistical package Eviews. 
As can be seen from Figure 2, kurtosis is located about 3, skewness - in area 0. From the residual plot (Fig. 3), we can conclude that there is no autocorrelation. In addition, based on the Breusch-Godfrey test, the $\mathrm{H}_{0}$ hypothesis was adopted about the absence of autocorrelation of residues in equation 2.

\section{Conclusion}

Financial sustainability can be approached in terms of microeconomics [29] and macroeconomics [30]. The study of financial sustainability began with a microeconomic perspective. However, a macroeconomic approach has emerged in the last decade. The financial sustainability of households is a level of their financial security. First, it frees households from constant concern for meeting urgent needs (food, clothing, housing, etc.). Secondly, it provides them with the necessary conditions for the reproduction of competitive human capital. Thirdly, it allows households to have a standard and quality of life that meets international standards. Fourth, it creates confidence in maintaining a sustainable standard of living and quality of life when social risks arise [4]. The financial sustainability of the household sector can also be interpreted as the ability of the household to implement the function of life support in various conditions [29]. The importance of household financial sustainability is based on the role of households in a market economy. Household finance is an element of society's financial system. The socio-economic essence of household finance is manifested in the totality of economic relations regarding the formation, distribution and use of funds [30]. Household debt soared before the global crisis of 2008 [31]. Credit has become available to low-income individuals, and it has become easier to borrow to buy housing. The 2008-2009 recession was triggered by the expansion of the housing sector and subsequent financial-sector crises, owing to over-borrowing by low-income individuals, particularly in the United States and Western Europe. An IMF study published in April 2012, World Economic Outlook in April 2012, found that recessions preceded by larger increases in household debt are more severe. This crisis underscores the importance of consumer credit and household finance management in determining the sustainability of the financial system and the level of economic activity. The rapid expansion of household lending creates a vulnerability that could precipitate a banking crisis. Another study shows that the crisis is usually related to more household debt. This may help explain why even moderate shocks can accelerate a huge wave of household defaults in a situation where households are already heavily indebted [32].

The paper discusses the main methods for assessing the financial sustainability of households, consisting in the problem of endogenousness, accessibility, quality and timeliness of statistical data on income and expenses, assets and liabilities of households. The authors propose to develop a single standard for assessing the financial vulnerability of households in Kazakhstan.

The complex of economic exogenous and endogenous factors affecting the financial sustainability of households in the Republic of Kazakhstan was determined in order to develop a model of the dynamics of retail NPL. From the obtained NPL regression model, we can conclude that the dynamics of NPL changes are affected by household debt with a lag of 1 quarter and consumer spending with a lag of 3 quarters.

\section{References}

1. N. Albacete, P. Fessler, Stress testing Austrian households. Financial Stability Report, 19. P.72-91. (2010) 
2. T. Bilston, D. Rodgers, A model for stress testing Household Lending in Australia. (RBA Bulletin, Reserve Bank of Australia. P. 27-38, (December, 2013).

3. K.Galuschak, Stress testing the Private Household Sector using microdata. (2017)

4. D. Handm, Modelling consumer credit risk IMA Journal of Management Mathematics, 12. P. 139 - 155. (2001)

5. L. Allen, G. DeLong, A. Saunders, Issues in the credit risk modeling of retail markets. Journal of Banking \& Finance, 28 - 4. P. 727-752. (2004)

6. E. Bartolozzi, L. Garcia-Erguin, C. Deocon, O. Vasquez, F. Plaza, Credit Scoring Modelling for Retail Banking Sector. II Modelling Week, Universidad Complutense de Madrid, 16th - 24th June. (2008)

7. V. Martin, K. Evien, Credit Scoring Methods. Journal of Economic Literature Accessed April 5, (2011) Retrieved from http://www.palgravejournals.com/jors/journal/v62/n4/full/jors201015a.html\#top

8. M. Pohar, M. Blas, S. Turk, Comparison of Logistic Regression and Linear Discriminant Analysis: A Simulation Study Metodološki zvezki, 1. P. $143-161$. (2004)

9. G. Webster, Bayesian Logistic Regression Models for Credit Scoring. (A thesis submitted to Rhodes University in partial fulfilment of the requirements for the degree of Master of Commerce. 2011)

10. M. Berry, G. Linoff, Mastering Data Mining: The Art and Science of Customer Relationship Management. Industrial Management \& Data Systems, 100 - 5. P. 245246. (2000) ISSN: 0263-5577. https://doi.org/10.1108/imds.2000.100.5.245.2

11. N. Siddiqi, Credit Risk Scorecards. (Published by John Wiley \& Sons, Inc. Hoboken, New Jersey. 2006)

12. A.U. Nesterov, Structure and mechanisms for maintaining household financial stability. Vestnik Universiteta, (2013)

13. N. Albacete, P. Lindner, Foreign currency borrowers in Austria - evidence from the Household Finance and Consumption Survey. (Financial Stability Report 29. P. 93109. 2015)

14. S. Dey, R. Djoudad, Y. Terajima, A tool for assessing financial vulnerabilities in the household sector. (Bank of Canada review, 2008)

15. M. Karasulu, Stresstesting Household Debt in Korea. (IMF Working paper. P. 255. 2008)

16. R. Djoudad, A Framework to Assess Vulnerabilities Arising from Household Indebtedness using Microdata. Aestimatio: The IEB International Journal of Finance, 3. P. 150-169. ISSN 2173-0164 (2011)

17. International Monetary Fund Annual Report 2012: Working Together To Support Global Recovery. Pages 76. (2012)

18. ECB. The Eurosystem Household Finance and Consumption Survey: Methodological Report for the first wave. (ECB Statistics Paper Series, 1. April. 2013)

19. V. Michelangeli, M. Pietrunti, A Microsimulation Model to Evaluate Italian Households' Financial Vulnerability. Bank of Italy Occasional Paper, 225. 34 Pages. (2015)

20. M. R. Arranz, M. Zavadjil, Are emerging Asia's reserves really too high? Chapter 4. Pages 30. (Book. Macroeconomic Policies in Indonesia. Indonesia economy since the Asian financial crisis of 1997)

21. V. Hlavac, M. Sonka, R. Boyle, Image Processing, Analysis, and Machine Vision. (Fourth Edition. Cengage Learning. Pages 853. 2014) 
22. T. Bilston, R. Johnson, M. Read, Research Discussion Paper Stress Testing the Australian Household Sector Using the HILDA Survey. (RDP 2015-01. Pages 35. 2015)

23. J. Meriküll, T. Rõõm, The financial fragility of Estonian households: Evidence from stress tests on the HFCS microdata, Bank of Estonia Working Paper, 4. (2017)

24. Basel Committee on Banking Supervision Annual Economic Report - 2019. https://www.bis.org/annualeconomicreports/index.htm? $\mathrm{m}=5 \% 7 \mathrm{C} 24$

25. M. Keese, Triggers and Determinants of Severe Household Indebtedness in Germany. Ruhr Economic Paper, 150. Pages 30. (2009)

26. G. D'Alessio, S. Iezzi, Household Over-Indebtedness: definition and measurement with Italian data. Questioni di Economia e Finanza (Occasional papers) from Bank of Italy, 149. P. 3.(2013)

27. Indicators of financial stability // National Bank of the Republic of Kazakhstan. February, 2018. http://www.nationalbank.kz/cont/ \%D0 \%98 \%D0 \%A4 \%D0 $\%$ A32.xls

28. B. De Clercq, Analysing the predictors of financial vulnerability of the consumer market microstructure in South Africa. (Doctoral dissertation. June, 2013)

29. L. Bimendiyeva, G. Sadykhanova, A. Bekmetova, Financial stability of the enterprise as an opportunity to ensure competitiveness. Proceedings of the 33rd International Business Information Management Association Conference, IBIMA 2019: Education Excellence and Innovation Management through Vision 2020, P. 4978-4983. (2019)

30. S. Kondybayeva, S. Abilday, B. Mukhamediyev, B. Baitanayeva, A. Abylay, Theoretical aspects of the shadow economy and it's current state in the world economy. Proceedings of the 31st International Business Information Management Association Conference, IBIMA 2018: Innovation Management and Education Excellence through Vision 2020. (2018)

31. K. Czerewacz-Filipowicz, The Russian Federation RTAs in the Light of Global Value Chains. Procedia Engineering, 182, P. 120-126. (2017)

32. S.K. Kondybayeva, Z.S. Ishuova, The effect of monetary policy on real house price growth in the republic of Kazakhstan: A vector autoregression analysis. World Applied Sciences Journal, 22 - 10, P. 1384-1394. (2013) 